\title{
Proposal for an "Althaeae flos (marshmallow flower)" Monograph set-up based on European Pharmacopoeia Template and Quality Evaluation of Commercial Samples
}

\author{
Esra Saçı ${ }^{1{ }^{*}}{ }^{*}$, Erdem Yeşilada ${ }^{1}$ \\ ${ }^{1}$ Yeditepe University, Faculty of Pharmacy, Department of Pharmacognosy, İstanbul, Turkey
}

\begin{abstract}
Although marshmallow flowers are used more frequently than leaves and roots, only Althaeae folium and Althaeae radix monographs exist in European Pharmacopoeia. The aim of study was to set standards for marshmallow flowers which will be used for its quality assessment. Althaeae flos monograph was prepared based on the main principles described in European Pharmacopoeia for herbal drugs. After setting the limits, the specifications of 33 marshmallow samples purchased from herbal markets were studied to determine their suitability for the proposed monograph. Results have shown that all the commercial samples were obtained not from Althaea, but Alcea species, a close gender, based on the flowers size. Since main characteristics of both flowers were determined to be identical, this would not rise a problem. However, residual parts of insects or snails were found in 28 samples and thus they were evaluated unacceptable to be used in phytotherapy.
\end{abstract}

Keywords: Althaeae flos, marshmallow flower, Malvaceae, monograph, quality

\section{INTRODUCTION}

There are 4 species represent of Althaea L. genus (Malvaceae) in "The Flora of Turkey and the East Aegean Islands". ${ }^{1}$ Among these species, Althaea officinalis L. (marshmallow) is indigenous to Turkish flora and it is native in Asia, Europe and China. ${ }^{2,3}$ In Turkey, A. officinalis is commonly named as "hatmi, tibbi hatmi, devegülü, fatma çiçeği, erkurtaran/ergurtaran çiçeği”. .7 $^{-7}$

The name of Althaea genus is derived from a word "althaino" that signifies "therapy, treatment" in Greek because of the healing potential of the plant and the species name "officinalis" signifies "to use in medicine". ${ }^{8}$

*Corresponding author: Esra Saçıcı, e-mail: esrascc@gmail.com

(Received 16 November 2017, accepted 22 November 2017) 
According to the studies on chemical constituents, astragalin ${ }^{9}, 4$-hydroxy-benzoic acid $^{10}$, ferulic acid ${ }^{10}$, hypolaetin 8-0-gentiobioside ${ }^{11}$, hypolaetin-4-0-methyl ether-8-o- $\beta$-D-glucoside ${ }^{11}$, dihydrokaempferol 4-0- $\beta$-D-glucoside ${ }^{11}$, dihydrokaempferol 4-o-glucoside ${ }^{9}$, naringenin-4-o- $\beta$-D-glucoside ${ }^{11}$, naringenin4-o-glucoside ${ }^{12}$, p-hydroxy-phenyl acetic acid $^{13,14}$, populnin ${ }^{10}$, protocatechuic $\operatorname{acid}^{14}$, isoquercitrin ${ }^{10}$, salicyclic acid ${ }^{13}$, scopoletin ${ }^{14}$, sinapic $\operatorname{acid}^{14}$, spiraeoside $^{12}$, syringic acid ${ }^{13}$, tiliroside ${ }^{15}$ and also vanillic acid ${ }^{10}$ were isolated from the flower parts of $A$. officinalis.

In vitro antioxidant effect of the flower extract from $A$. officinalis was investigated and reported to possess strong antioxidant effect, i.e., significant metal chelating, superoxide anion radical scavenging, free radical scavenging and reducing power actions. ${ }^{16}$ In another study, the total flavonoids content and the antioxidant properties of Althaeae flos were comparatively determined in terms of the petal colors, including white, pink and reddish pink. Although white petals possessed the highest flavonoid content, reddish-pink colored petals exhibited the highest antioxidant activity. ${ }^{17}$

In a study, possible role of the aqueous extract of Althaeae flos in platelet aggregation, lipemia, inflammation and gastric ulcer was examined in rats. It was reported that platelet aggregation was inhibited time-dependently. Serum HDL-cholesterol level was significantly increased, while no effects on stool cholesterol and triacylglycerol were observed. The aqueous extract also showed anti-inflammatory activity on acute and chronic inflammation models and also anti-ulcerogenic effect was reported without any apparent adverse effect. ${ }^{18}$ In another study, hexane extract of Althaeae flos collected from northwestern Iran was found to contain fatty acid composed of alpha-linolenic acid, palmitic acid, heptacosane and nonacosane, and the extract displayed a good antimicrobial activity against Bacillus subtilis, Enterococcus faecalis, Staphylococcus aureus, Escherichia coli, Candida albicans and Saccharomyces cerevisiae. ${ }^{19}$

Roots and leaves of Althaea species have been used in traditional medicines worldwide for centuries as expectorant, demulcent, diuretic, and emollient for the treatment of cough, upper respiratory tract inflammations, gastritis, peptic ulceration, renal (i.e. cystitis) and uterine disorders. ${ }^{20-23}$ However records for use of its flowers in traditional medicines are rare. Hot water extract prepared from the dried marshmallow flowers was utilized externally (in Peru) ${ }^{24}$ or orally (in France) ${ }^{25}$ as an emollient or as expectorant in India. ${ }^{26}$ Additionally, decoctions prepared from the flowers and leaves were taken orally against asthmatic symptoms in Italy. ${ }^{27}$ In Greece, root and flowers of $A$. officinalis have found a wide range of applications including coronary disorders, hypertension, consti- 
pation, diarrhea, enteritis, gastritis, stomatitis, cystitis, kidney stones, nephritis, blood purification, laryngitis, pharyngitis, common cold, bronchitis, aphthae, gum wounds and pimples. ${ }^{28}$ In the Iranian traditional documents, the flowers, leaves or roots of $A$. officinalis have all been suggested orally for gastrointestinal and respiratory system inflammations as well as externally for burns and insect stings. ${ }^{29}$ Furthermore, as an evidence of safety of $A$. officinalis, it is listed by the Council of Europe in category N2 as a natural food as well as in the United States. ${ }^{22,30,31}$

In Turkey, infusions obtained from marshmallow flowers have been used internally for bronchial complaints, cough and cold due to its rich mucilage content. ${ }^{5,32}$ Decoction of marshmallow root have been used internally for the treatment of gastritis, peptic, mouth and throat ulcerations as well as for respiratory tract irritations as gargle. ${ }^{4}$ In East Anatolia, infusion obtained from A. officinalis aerial parts has been used as diuretic and antilithic in the treatment of kidney stone or sand. ${ }^{33}$ It is reported that in Aydınck district (Mersin), infusion prepared from $A$. officinalis herb has also been used orally as one teacup 3 times per day for 2-3 weeks or used as gargle for 3-5 successive days against stomachache, as well as asthma, cold and flu symptoms.7 [Note: In both studies the plant part used as remedy was specified as "herb"]. Moreover, Althaea roots are externally applied on wounds to keep the skin soft and for wound-healing. ${ }^{4}$

Despite A. officinalis flowers have found a place in traditional medicinal practice, in the European Pharmacopoeia (Ph. Eur.), only the qualifications of its roots and leaves are described under two monographs; Marshmallow leaf (Althaeae folium) ${ }^{34}$ and Marshmallow root (Althaeae radix) ${ }^{35}$. Although in French Pharmacopoeia the flowers were registered together with the roots and leaves as a herbal drug for the treatment of cough, but no specification was described except the common macroscopic and microscopic characteristics. ${ }^{36}$ On the other hand, in Turkey only the dried flowers of the plant have been available in the herbal drug market, the official herbal drugs, i.e., roots or leaves of marshmallow, are not available. Eventually, there is no official data to describe the specifications of marshmallow flowers to determine its qualification. Therefore, the first aim of the present study was to define the macroscopical, microscopical and chemical characteristics of marshmallow flowers. Secondly, a draft monograph proposal for "Althaeae flos (marshmallow flower)" was suggested to set the standards for the herbal drug by predicating on the analysis criteria in the Ph. Eur. In compliance with the proposed template, quality evaluation was carried out on the marshmallow flower samples purchased from herbal shops. 


\section{MATERIALS AND METHODS}

\section{Plant materials and solvents}

Thirty-three samples of marshmallow flowers were purchased from local herb markets in İstanbul and Tekirdağ (Turkey). The other herbal material Alcea sp. flowers collected from Karaman, Konya (Turkey) in order to be used in this work and they were dried in shade. In this study, specimens of marshmallow were encoded as A1-A33 throughout the study for reasons of confidentiality. All of these herbs were powdered by a laboratory mill. Ethanol and sulphuric acid were from Sigma-Aldrich (Steinheim, Germany); acetic acid, $n$-butanol and methanol were purchased from Riedel-de Haën (Seelze, Germany), Fluka (Steinheim, Germany) and Analar Normapur (Muarrie, Australia), respectively.

\section{Methods}

\section{Macroscopic examination}

The morphological characteristics of the whole materials were determined under the Stems DV4/DR Carl Zeiss binocular loop. Epicalyx, calyx, corolla, stamen, filament, anther, ovary, stylus and pedicel parts of these materials were evaluated. In addition, the petal lengths of marshmallow flowers and Alcea sp. flowers were measured by a ruler.

\section{Microscopic examination}

The microscopic properties of the powdered materials were determined under a Carl Zeiss AxioVision electronical microscope and a Nikon E20o microscope using chloral hydrate solution. Characteristic elements i.e. curved, stellate or glandular trichomes, calcium oxalate crystals, pollen grains and stomata were examined.

\section{Detection offoreign matter}

The amounts of foreign organs and foreign elements of the entire flower materials were calculated according to the technique for determination of foreign matter described under Methods in Pharmacognosy in the Ph. Eur. 50-100 g of the whole samples were weighed. Then, they were spread on a white paper and insects, snails, feathers, bristles and stones were separated by examining with unaided eye as well as a magnifying glass. The removed foreign materials were simply weighed and the percentages were calculated.

\section{Loss on drying experiment}

The quantities of losses on drying of all the samples were evaluated according to technique for loss on drying under Physical and Physicochemical Methods in 
the Ph. Eur. $1 \mathrm{~g}$ of the whole material was weighed in capsules, and dried in the drying oven at $105{ }^{\circ} \mathrm{C}$ for 2 hours. Then, capsules were cooled, reweighed, and the percentages were calculated.

\section{Total ash experiment}

The ash amount of each material was determined according to the method described under Limit Tests in the Ph. Eur. for total ash. All the crucibles were heated for 30 minutes, cooled in a desiccator and tares of them were weighed. 1 $\mathrm{g}$ of the powdered substance was weighed in a crucible, and then was ignited in a furnace at $600{ }^{\circ} \mathrm{C}$. After each burning, the crucible was removed from furnace, cooled in a desiccator and weighed when it was cool and then the total ash percentage was calculated.

\section{Swelling index experiment}

The swelling index of all samples were calculated according to the method described under Methods in Pharmacognosy in the Ph. Eur. $0.2 \mathrm{~g}$ of each of the powdered material was weighed and put in a $25 \mathrm{~mL}$ ground-glass stoppered special cylinder graduated in $0.5 \mathrm{~mL}$ divisions. The material was first humidified with $0.5 \mathrm{~mL}$ of ethanol, and $25 \mathrm{~mL}$ of distilled water was added. Then each glass cylinder was enclosed and shaken every ten minutes for one hour period, and left to stand for three hours. After 90 minutes from the start of the experiment, the cylinders were turned around their axes in order to mix large volumes of liquid retained in the layer of the drugs and fragments of these drugs floating on the top of the liquid. At the end of the test, the volume occupied by the swelling drug, which indicates mucilage content, was measured. Three individual experiments were performed for each material at the same time. The average of three trials was estimated as the swelling index.

\section{High Performance Thin-Layer Chromatography (HPTLC) analysis}

The analyses were carried out on alumina HPTLC plates covered with silica gel $60 \mathrm{~F}_{254}$ (Merck, Darmstadt, Germany). $1 \mathrm{~g}$ of each powdered material was weighed, and $10 \mathrm{~mL}$ of $60 \%$ ethanol was added. After stirring for $15 \mathrm{~min}$, they were filtered to prepare test solutions. These solutions were applied on the plates as $9.0 \mathrm{~mm}$ bands by a mean of $100 \mu \mathrm{L}$ syringe (Hamilton, Bonaduz, Switzerland) via Camag Linomat V sample applicator (Muttenz, Switzerland). The plates were developed in a twin through glass chamber saturated with the mobile phase. The same mobile system [acetic acid-water-butanol (15:30:60, v/v/v)] recorded in "Malvae sylvestris flos" monograph in Ph. Eur. was used. After developing the plates, they were dried. Chromatograms were displayed by exposing to UV-light at $366 \mathrm{~nm}$ using Camag TLC Visualizer. Then, the plates were sprayed with sul- 
phuric acid $5 \%$ in methanol $\left(\mathrm{H}_{2} \mathrm{SO}_{4}\right)$ reagent. The derivatized plates were heated at $105{ }^{\circ} \mathrm{C}$ and documented. All the devices were managed by WinCATS software.

\section{RESULTS}

The findings of thirty-three marshmallow samples and Alcea sp. materials were evaluated by using the data presented under "Malvae sylvestris flos" monograph in the Ph. Eur. ${ }^{37}$ This monograph was used as a guiding reference because Malva sylvestris is a close member to Althaea sp. from the same family.

\section{Macroscopic results}

Macroscopic examinations of all commercial marshmallow materials demonstrated that they had similar morphological features to Alcea sp. On the other hand, petal lengths of all these marshmallow materials were not within the limits specified for Althaea L. in "The Flora of Turkey and the East Aegean Islands", but they were similar to that of the Alcea sp. (Table 1). The morphological findings obtained by macroscopic analyses are given in Table 2.

Table 1. Comparative macroscopic characteristics of Althaea L. and Alcea L.38,39

\begin{tabular}{|l|l|l|}
\cline { 2 - 3 } \multicolumn{1}{c|}{} & \multicolumn{1}{c|}{ Alcea L. } & \multicolumn{1}{c|}{ Althaea L. } \\
\hline Epicalyx & $\begin{array}{l}\text { generally 6, rarely 7-9 partite } \\
\text { connate }\end{array}$ & $\begin{array}{l}\text { 6-9 partite } \\
\text { connate at the base }\end{array}$ \\
\hline Petal & 30 mm or longer & up to $16 \mathrm{~mm}$ \\
\hline Anther & yellowish & brownish-purple \\
\hline Carpel & sub-bilocular & unilocular \\
\hline
\end{tabular}




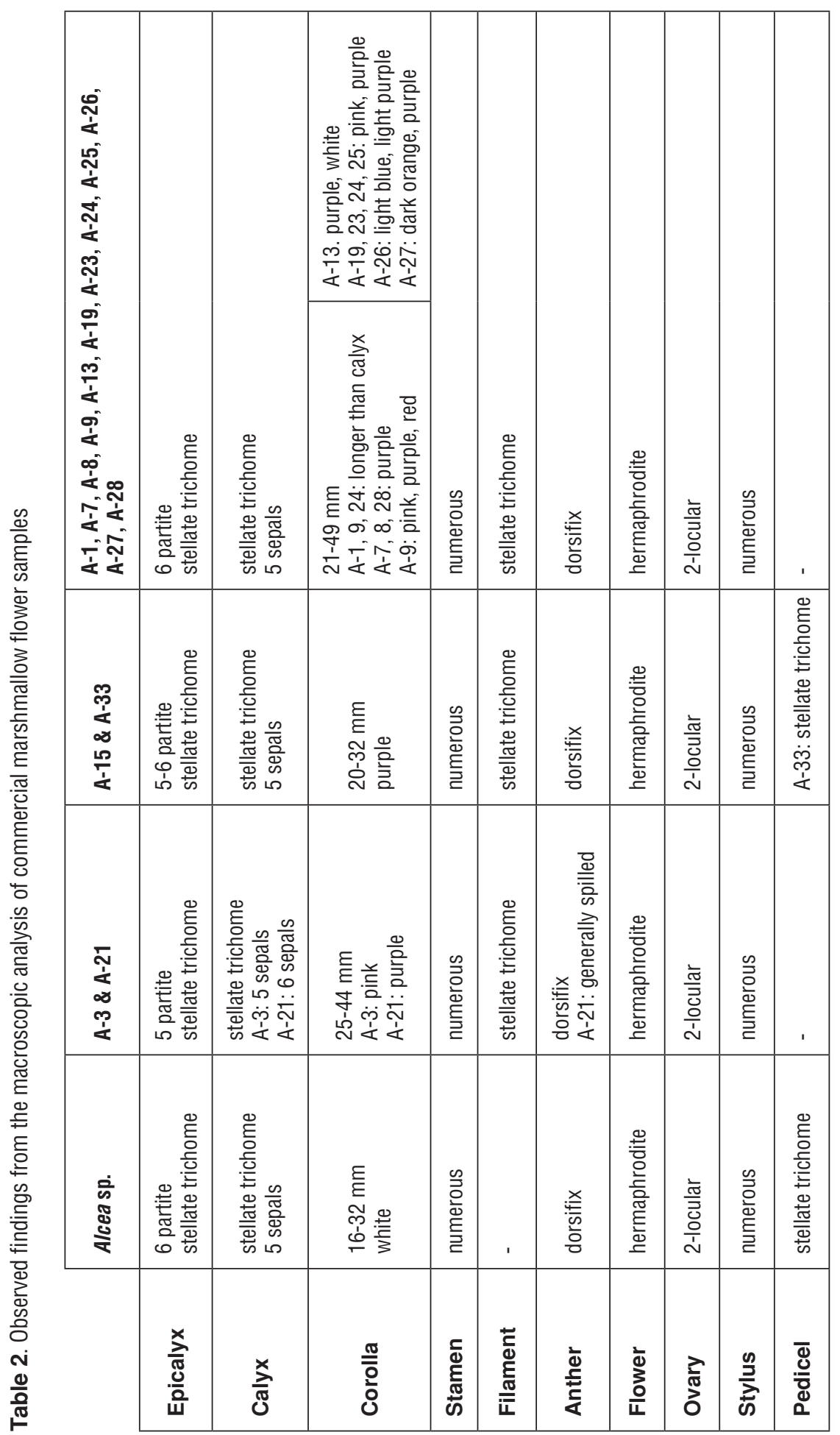




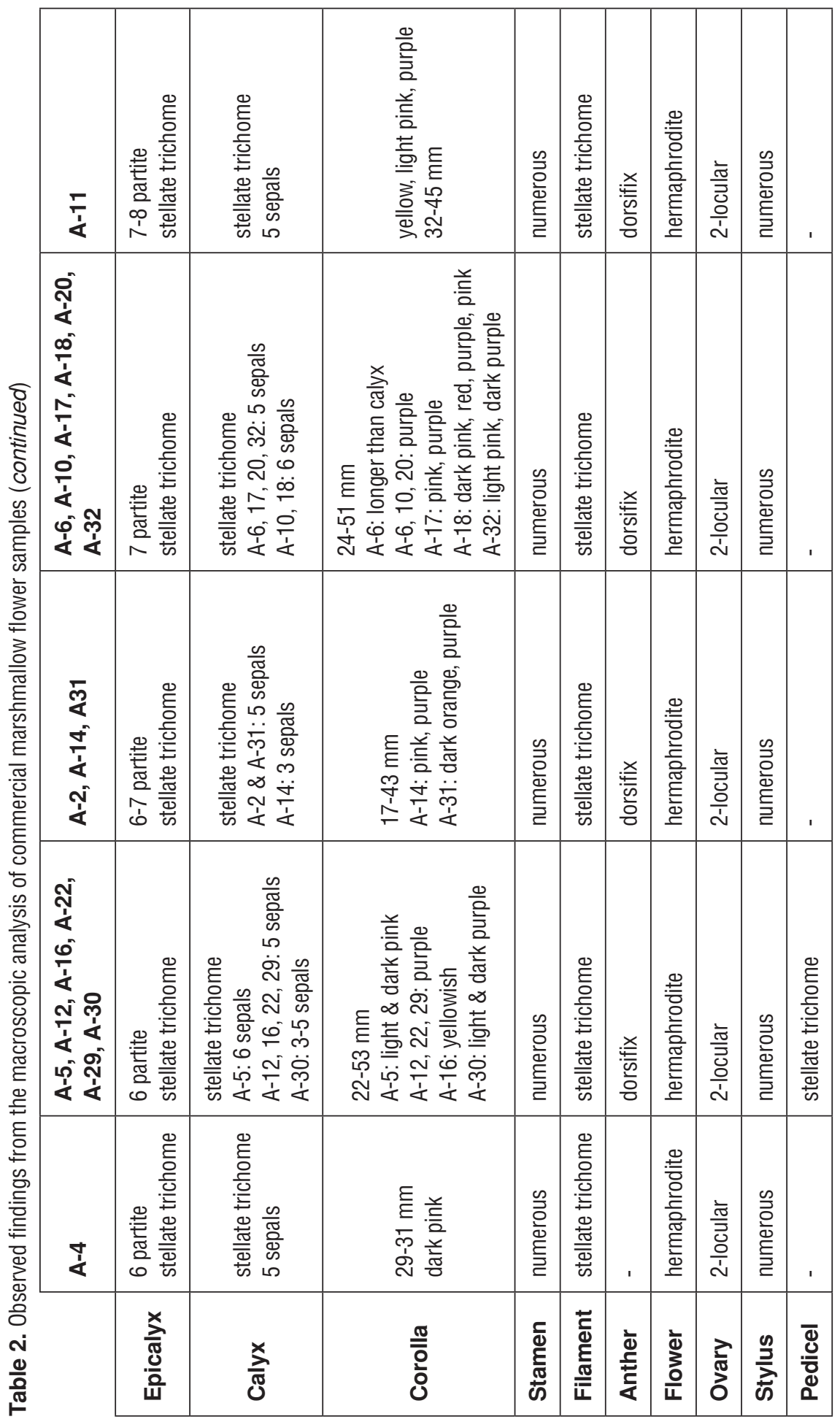




\section{Results of Microscopic Analysis}

The microscopic analysis of all commercial marshmallow samples exhibited that they had similar microscopic characteristics to Alcea sp. (Figure 1). Additionally, stomata of A-2, 5, 10, 22, 32 and 33 had 3 subsidiary cells as well as only A-3 had the Malvaceae type glandular trichome. The microscopic findings are presented in Table 3 .

a

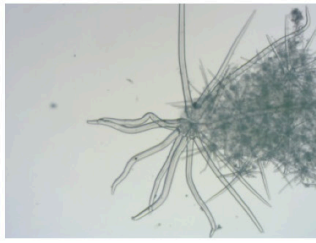

d

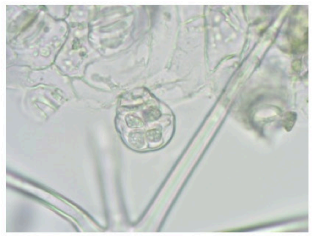

g

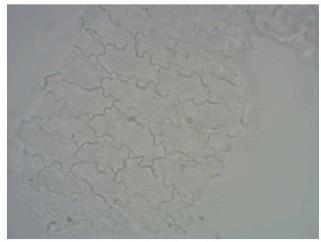

b

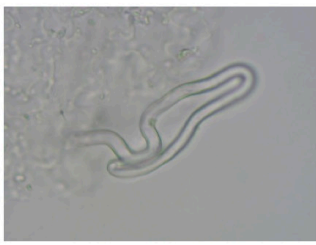

c

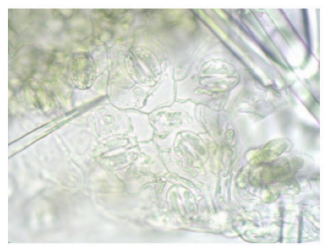

e

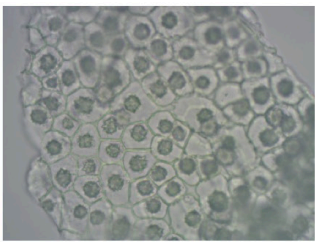

f

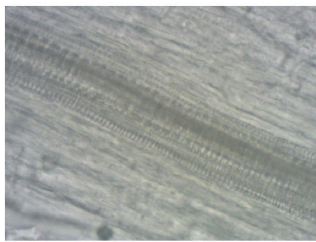

h

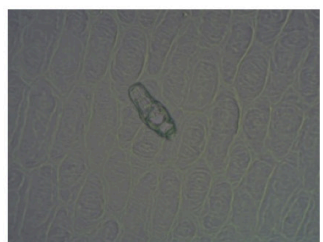

i

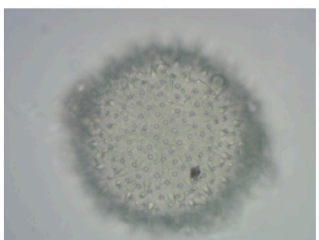

Figure 1. Microscopic illustrations of Alcea sp.: (a) stellate trichome (4x); (b) curved trichome (40x); (c) stomata (40x); (d) glandular trichome (40x); (e) cluster crystals of calcium oxalate (40x); (f) vessel (40x); (g) petal epidermis (40x); (h) glandular trichome in petal (40x); (i) pollen grain (40x). 


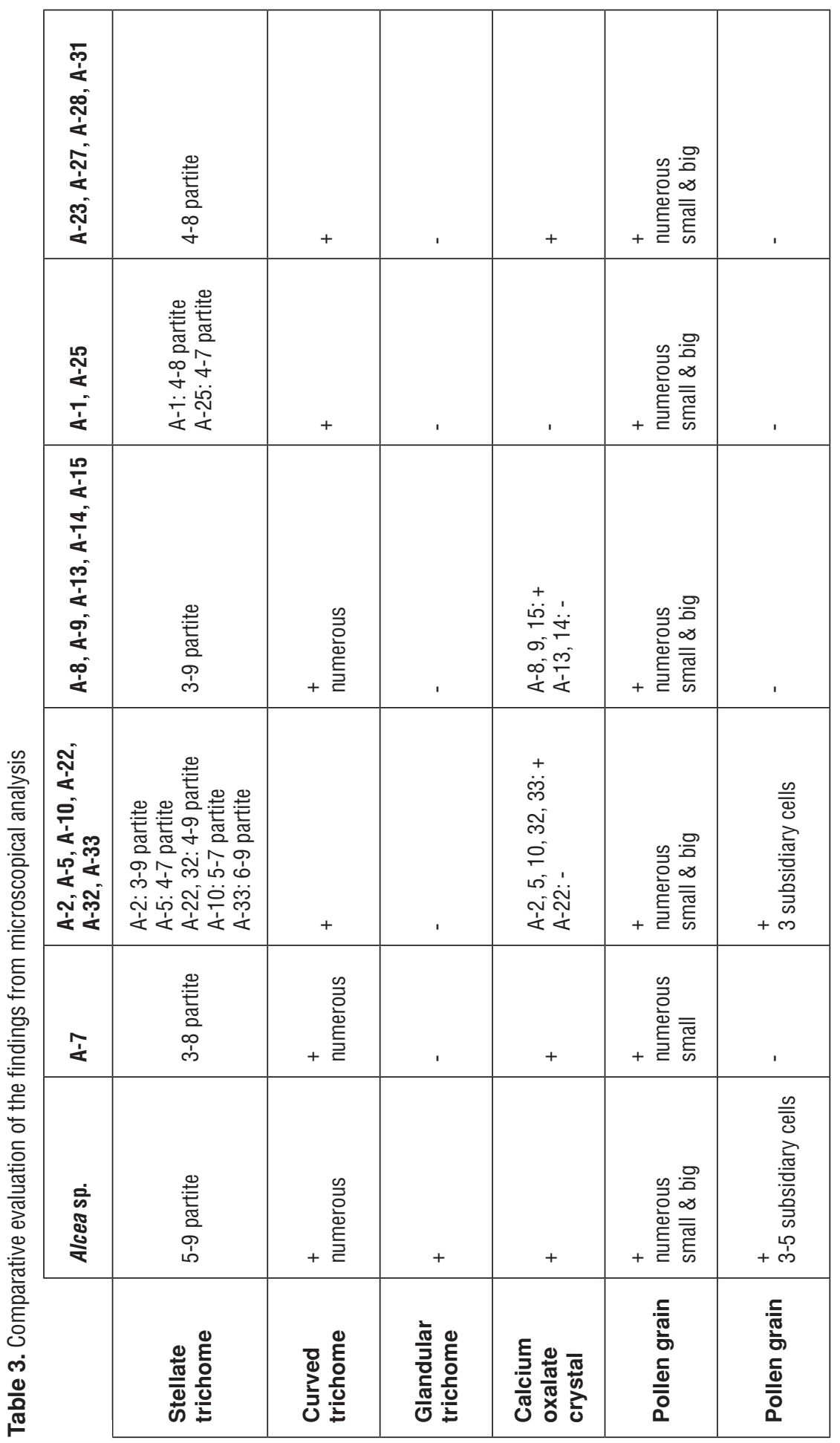




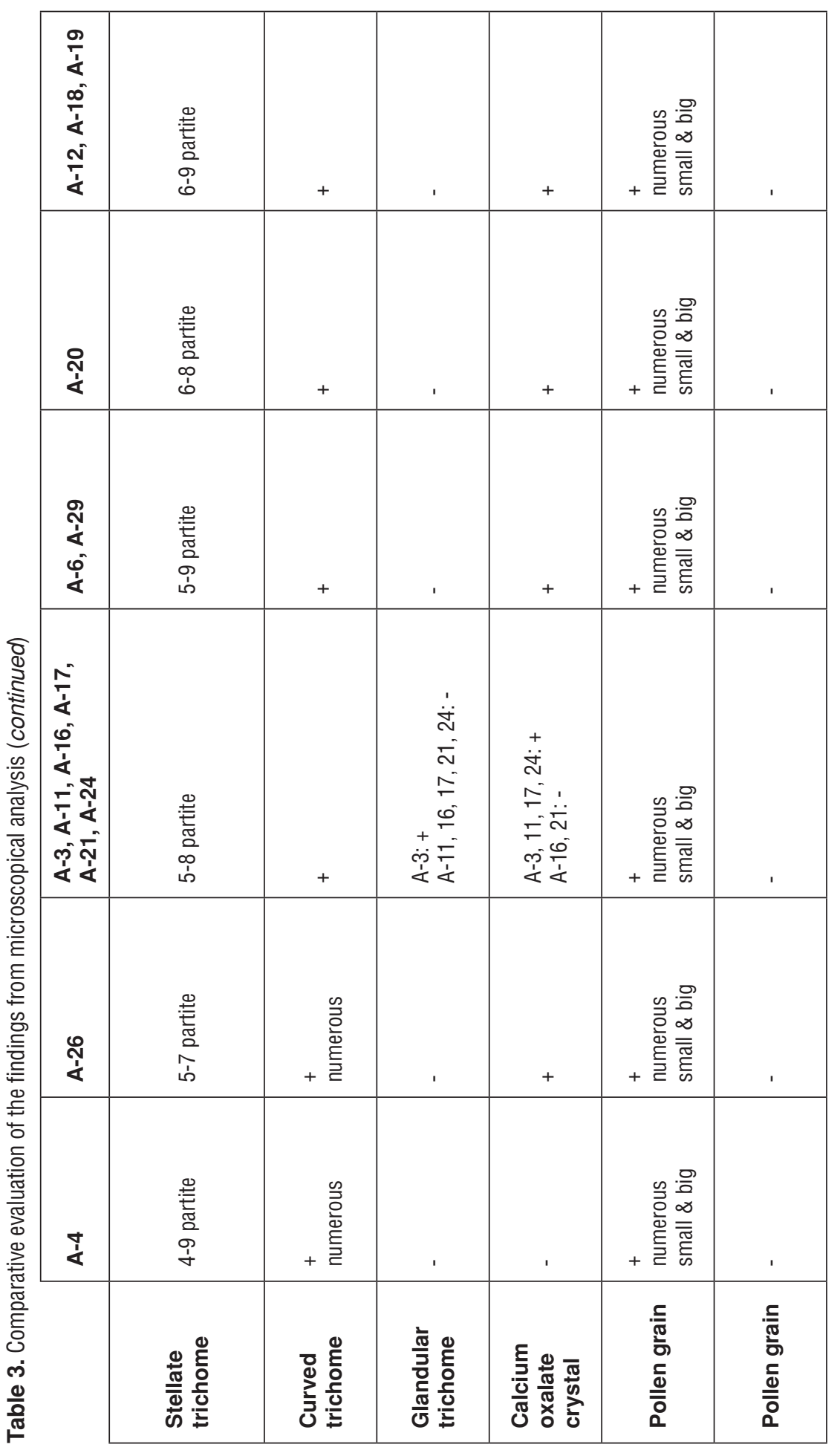




\section{Foreign Matter}

The ratio of foreign matter is set at maximum 2.0 per cent $(\mathrm{w} / \mathrm{w})$ as described at the general pharmacopoeia rules. Accordingly, 27 of 33 commercial marshmallow specimens were found to be lower than this ratio, while the percentages of the remaining six marshmallow materials [A-3, 16, 22, 27, 30, and 31] were over 2.0\% (Figure 2). On the other hand, insects or insect parts and snails were detected in 26 among the 33 marshmallow samples, therefore they cannot be considered as safe herbal drugs. Among the remaining seven samples which did not contain insects and snails, two samples were previously eliminated due to high ratio of foreign matter. Consequently, only five samples [A-11, 12, 13, 18, and 19] were considered to be appropriate herbal drug. The percentages of foreign organs and foreign elements are given in Table 4.

a

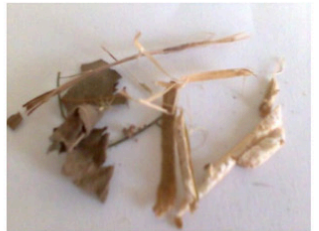

d

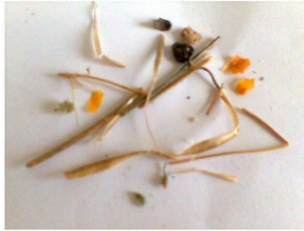

g

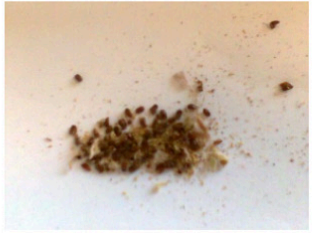

j

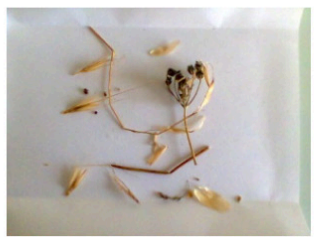

b

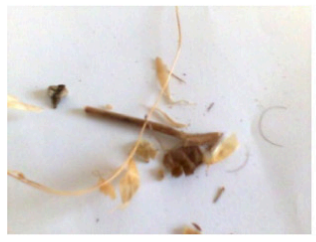

$\mathbf{e}$

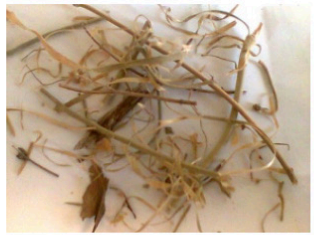

h

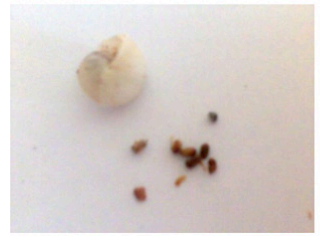

k

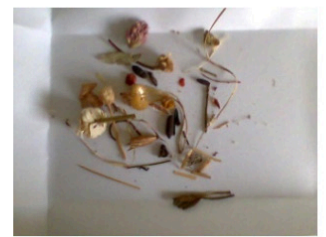

c

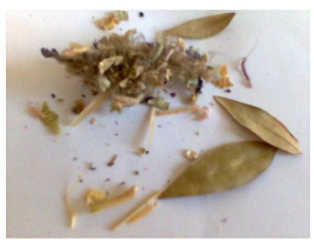

f

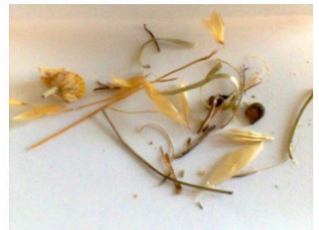

i

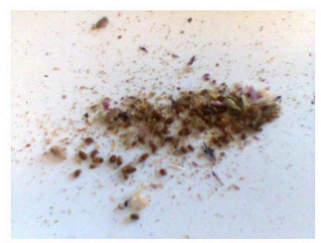

1

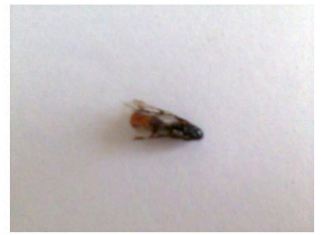

Figure 2. Foreign substances detected in marshmallow samples. (a) feather \& different plant parts in A-3; (b) feather, bristle \& different plant parts in A-7; (c) different plant parts in A-13; (d) stone \& different plant parts in A-15; (e) different plant parts in A-16; (f) stone \& different plant parts in A-20; $(\mathrm{g})$ insects in A-21; (h) insects \& snail in A-23; (i) insects in A-24; (j) different plant parts in A-29; (k) feather \& different plant parts in A-30; (I) insect in A-32. 
Table 4. Findings of foreign matter

\begin{tabular}{|c|c|c|c|}
\hline Samples & $\begin{array}{c}\text { Insects/Snails } \\
(\%)\end{array}$ & $\begin{array}{c}\text { Feathers/Bristles/Stones/ } \\
\text { Foreign plant parts } \\
(\%)\end{array}$ & $\begin{array}{c}\text { Total } \\
\text { foreign matter } \\
(\%)\end{array}$ \\
\hline$A-1$ & 0.029 & - & 0.029 \\
\hline$A-2$ & 1.526 & 0.440 & 1.966 \\
\hline A-3 & - & 5.696 & 5.696 \\
\hline$A-4$ & 0.399 & - & 0.399 \\
\hline$A-5$ & 0.023 & 0.303 & 0.326 \\
\hline$A-6$ & 0.021 & 0.055 & 0.076 \\
\hline$A-7$ & 0.017 & 0.264 & 0.281 \\
\hline$A-8$ & 0.018 & 0.311 & 0.329 \\
\hline$A-9$ & 0.028 & 0.007 & 0.035 \\
\hline$A-10$ & 0.109 & 0.612 & 0.721 \\
\hline$A-11$ & - & 0.857 & 0.857 \\
\hline$A-12$ & - & 0.038 & 0.038 \\
\hline$A-13$ & - & 0.903 & 0.903 \\
\hline$A-14$ & 0.006 & 0.212 & 0.218 \\
\hline$A-15$ & 0.017 & 0.300 & 0.317 \\
\hline$A-16$ & - & 2.792 & 2.792 \\
\hline$A-17$ & 1.529 & - & 1.529 \\
\hline$A-18$ & - & 0.843 & 0.843 \\
\hline$A-19$ & - & 0.158 & 0.158 \\
\hline$A-20$ & 0.695 & 0.498 & 1.193 \\
\hline$A-21$ & 0.235 & 0.215 & 0.450 \\
\hline$A-22$ & 2.169 & - & 2.169 \\
\hline A-23 & 0.239 & 0.429 & 0.668 \\
\hline A-24 & 0.285 & 0.123 & 0.408 \\
\hline A-25 & 0.010 & 0.077 & 0.087 \\
\hline A-26 & 0.003 & 1.994 & 1.997 \\
\hline$A-27$ & 0.051 & 4.336 & 4.387 \\
\hline$A-28$ & 0.015 & 0.940 & 0.955 \\
\hline$A-29$ & 0.064 & 0.410 & 0.474 \\
\hline A-30 & 0.007 & 2.363 & 2.370 \\
\hline$A-31$ & 0.069 & 2.618 & 2.687 \\
\hline A-32 & 0.021 & 1.264 & 1.285 \\
\hline A-33 & 0.101 & 0.641 & 0.742 \\
\hline
\end{tabular}




\section{Loss on Drying}

The limit of loss on drying was set at maximum 12.0 per cent (w/w) similarly to set value in "Malvae sylvestris flos" monograph [Ph. Eur.]. Accordingly, in 28 samples the rates were found to be lower [between 9.74 and 11.94 for A-1 to A-4, A-6 to A-16, A-18 to A-20, A-22, A-23, and A-26 to A-33], while in five samples $[\mathrm{A}-5,17,21,24,25]$ and reference Alcea sp. the ratio was higher than $12.0 \%$ [between 12.28 and 13.25].

\section{Total Ash}

In the "Malvae sylvestris flos" monograph total ash limit was set at maximum 14.0 per cent (w/w). Accordingly, the total ash amount of all the commercial marshmallow samples [between 8.36 and 11.63 for A-1, A-2, A-4 to A-33] and Alcea sp. sample have remained below this limit. The ash content of only A-3 was somewhat closer to $14.0 \%$ [13.52\%].

\section{Swelling Index}

Swelling index was determined following the "Malvae sylvestris flos" monograph [Ph. Eur.] and the limit therein was at least 15. In this regard, the swelling indices of all marshmallow specimens and Alcea sp. sample were far below the limit value. Besides, the greatest swelling indices were obtained from only A-24 and A-25. The swelling indices are presented in Table 5 . 
Table 5. Findings of swelling index

\begin{tabular}{|c|c|c|c|c|}
\hline Samples & Trial-I & Trial-II & Trial-III & Mean \\
\hline Alcea sp. & 7.25 & 7.00 & 6.50 & 6.92 \\
\hline$A-1$ & 3.00 & 4.25 & 3.00 & 3.42 \\
\hline$A-2$ & 3.50 & 5.50 & 3.50 & 4.17 \\
\hline A-3 & 6.00 & 8.50 & 7.50 & 7.33 \\
\hline$A-4$ & 6.00 & 4.50 & 5.50 & 5.33 \\
\hline$A-5$ & 6.00 & 8.50 & 7.00 & 7.17 \\
\hline$A-6$ & 4.50 & 4.00 & 4.00 & 4.17 \\
\hline$A-7$ & 4.00 & 4.50 & 3.50 & 4.00 \\
\hline$A-8$ & 4.50 & 4.00 & 4.50 & 4.33 \\
\hline$A-9$ & 4.50 & 5.00 & 4.50 & 4.67 \\
\hline$A-10$ & 3.50 & 4.00 & 3.00 & 3.50 \\
\hline$A-11$ & 5.50 & 5.00 & 4.50 & 5.00 \\
\hline$A-12$ & 7.00 & 5.00 & 5.00 & 5.67 \\
\hline$A-13$ & 5.50 & 6.00 & 5.00 & 5.50 \\
\hline A-14 & 4.50 & 3.00 & 3.50 & 3.67 \\
\hline$A-15$ & 5.00 & 5.50 & 6.50 & 5.67 \\
\hline$A-16$ & 3.00 & 3.00 & 2.25 & 2.75 \\
\hline A-17 & 4.50 & 6.00 & 4.50 & 5.00 \\
\hline$A-18$ & 4.00 & 5.50 & 5.00 & 4.83 \\
\hline$A-19$ & 4.00 & 4.50 & 4.50 & 4.33 \\
\hline A-20 & 5.00 & 4.50 & 5.00 & 4.83 \\
\hline$A-21$ & 4.50 & 3.00 & 4.00 & 3.83 \\
\hline A-22 & 5.50 & 3.25 & 4.00 & 4.25 \\
\hline A-23 & 4.00 & 5.50 & 3.50 & 4.33 \\
\hline A-24 & 6.50 & 9.50 & 8.00 & 8.00 \\
\hline A-25 & 8.00 & 8.50 & 8.50 & 8.33 \\
\hline A-26 & 4.50 & 5.50 & 6.00 & 5.33 \\
\hline $\mathrm{A}-27$ & 6.50 & 8.00 & 6.50 & 7.00 \\
\hline A-28 & 7.50 & 6.50 & 9.00 & 7.67 \\
\hline A-29 & 5.50 & 3.00 & 4.00 & 4.17 \\
\hline A-30 & 4.00 & 4.50 & 3.00 & 3.83 \\
\hline $\mathrm{A}-31$ & 5.00 & 4.00 & 3.50 & 4.17 \\
\hline A-32 & 2.50 & 3.50 & 3.00 & 3.00 \\
\hline$A-33$ & 4.00 & 2.75 & 4.50 & 3.75 \\
\hline
\end{tabular}




\section{HPTLC Analysis}

The fingerprints of the test solutions prepared from the flowers of all commercial marshmallow materials as well as the flower, corolla and calyx parts of reference Alcea sp. sample were compared (Figure 3, 4, 5, 6 and 7). Under $366 \mathrm{~nm}, \mathrm{~A}-4,5$, 9, 11, 12, 13, 17, 18, 19, 21, 23, 24, 25 and 32 showed two blue fluorescent zones and red fluorescent spot in the upper part of plate. Moreover, blue fluorescent zones at $\mathrm{R}_{\mathrm{f}} \mathrm{O} .5$ and 0.9 were seen in $\mathrm{A}-8,10,12,14,18,20,22,28,29,30,31$ and 33. Furthermore, this blue zone was also detected in the flower, corolla and calyx parts of Alcea sp. Besides, after spraying with $\mathrm{H}_{2} \mathrm{SO}_{4}$ reagent, under white light, blackish yellow zone between $R_{f} 0.2$ and 0.4 was observed in A-4, 5, 9, 11, 12, 13, $17,18,19,24,25$ and 32 . In addition, they exhibited a dark yellow zone at $R_{f} 0.8$, so they were similar to each other.

a

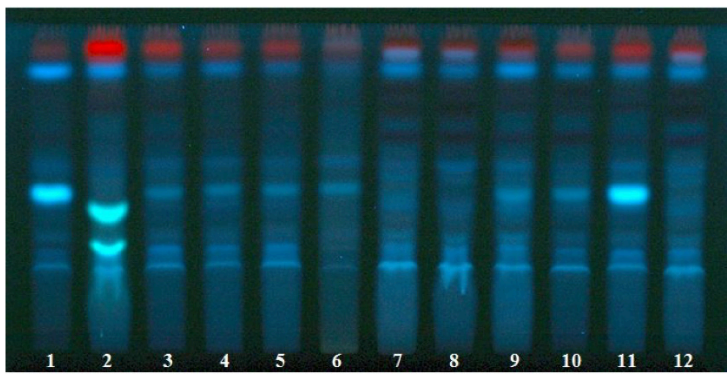

b

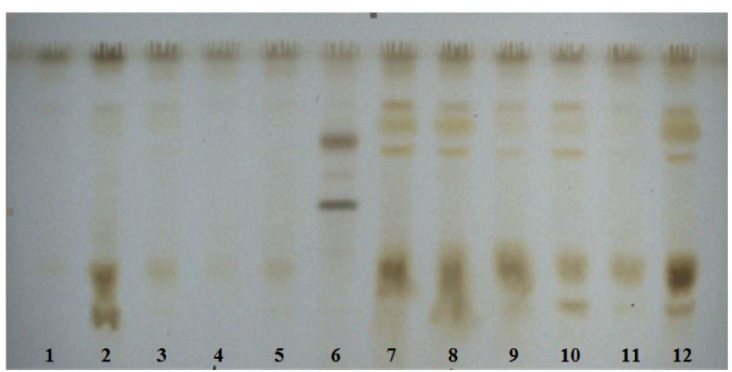

Figure 3. HPTLC chromatogram-1 visualized (a) at $366 \mathrm{~nm}$; (b) under white light. Mobile phase: acetic acid-water-butanol (15:30:60, v/v/v); applied volumes: Mallow-7 $\mu \mathrm{L}$, other extracts-9 $\mu \mathrm{L}$, derivatization: $\mathrm{H}_{2} \mathrm{SO}_{4}$ reagent. Tracks: (1) Alcea sp. (reference); (2) mallow; (3) A-15; (4) A-1; (5) A-2; (6) A-3; (7) A-4; (8) A-5; (9) A-6; (10) A-7; (11) A-8; (12) A-9. 
$\mathbf{a}$

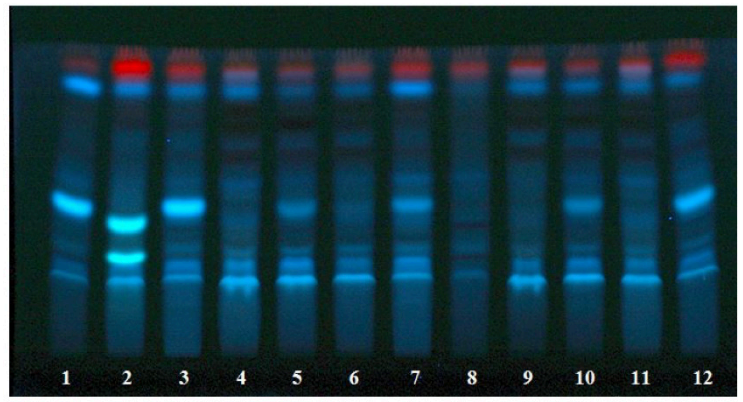

b

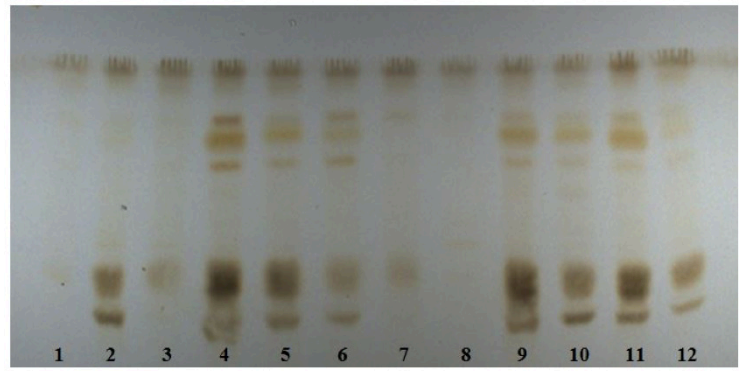

Figure 4. HPTLC chromatogram-2 visualized (a) at $366 \mathrm{~nm}$; (b) under white light. Mobile phase: acetic acid-water-butanol (15:30:60, v/v/v), applied volumes: Mallow-7 $\mu \mathrm{L}$, other extracts-9 $\mu \mathrm{L}$, derivatization: $\mathrm{H}_{2} \mathrm{SO}_{4}$ reagent. Tracks: (1) Alcea sp. (reference); (2) mallow; (3) A-10; (4) A-11; (5) A-12; (6) A-13; (7) A-14; (8) A-16; (9) A-17; (10) A-18; (11) A-19; (12) A-20.

a

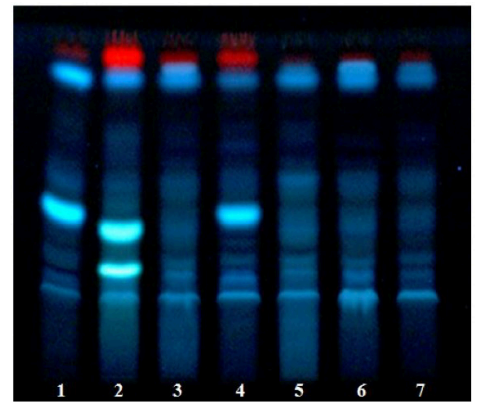

b

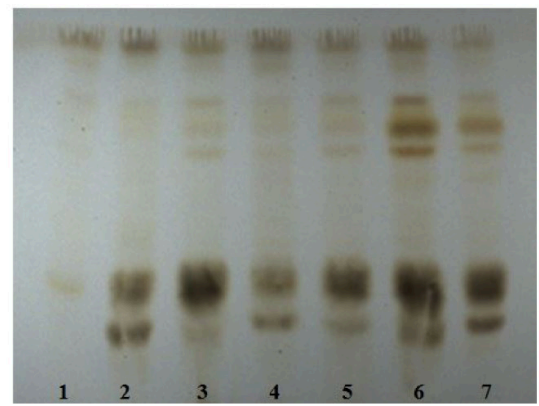

Figure 5. HPTLC chromatogram-3 visualized (a) at $366 \mathrm{~nm}$; (b) under white light. Mobile phase: acetic acid-water-butanol (15:30:60, v/v/v), applied volumes: Mallow-7 $\mu \mathrm{L}$, other extracts-9 $\mu \mathrm{L}$, derivatization: $\mathrm{H}_{2} \mathrm{SO}_{4}$ reagent. Tracks: (1) Alcea sp. (reference); (2) mallow; (3) A-21; (4) A-22; (5) A-23; (6) A-24; (7) A-25. 
a

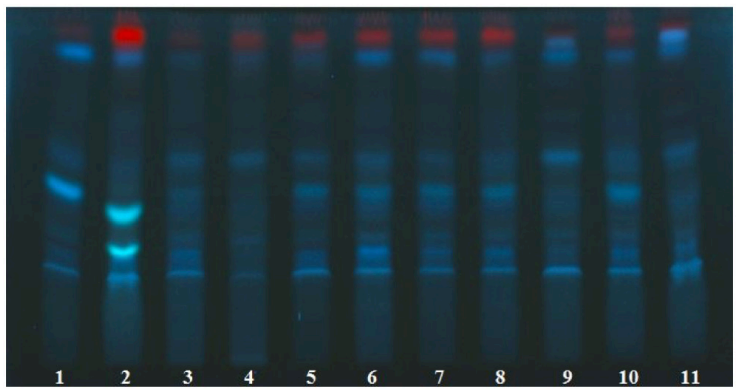

b

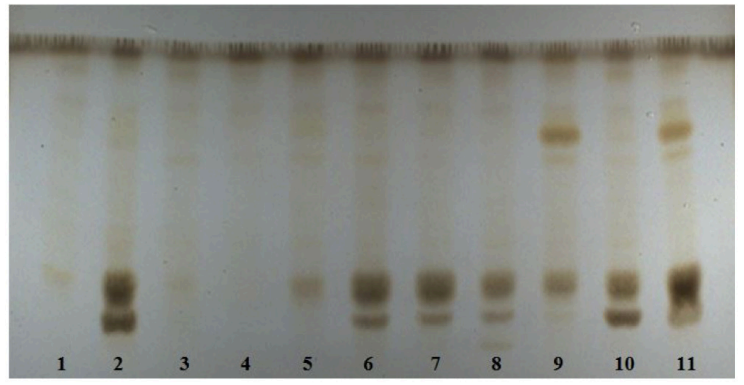

Figure 6. HPTLC chromatogram-4 visualized (a) at $366 \mathrm{~nm}$; (b) under white light. Mobile phase: acetic acid-water-butanol (15:30:60, v/v/v), applied volumes: Mallow-7 $\mu \mathrm{L}$, other extracts-9 $\mu \mathrm{L}$, derivatization: $\mathrm{H}_{2} \mathrm{SO}_{4}$ reagent. Tracks: (1) Alcea sp. (reference); (2) Mallow; (3) A-26; (4) A-27; (5) A-28; (6) A-29; (7) A-30; (8) A-31; (9) A-32; (10) A-33; (11) A-5.

a

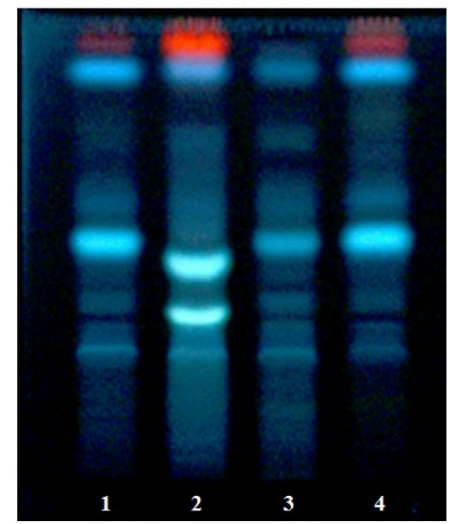

b

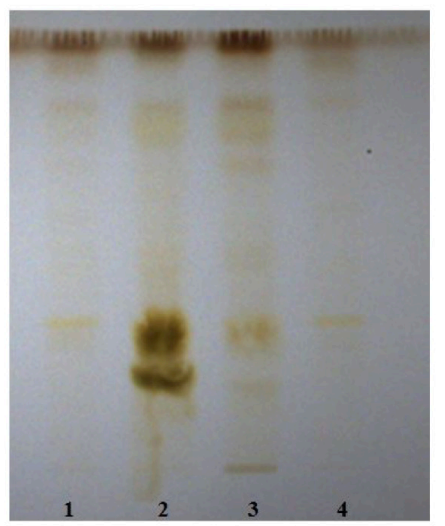

Figure 7. HPTLC chromatogram-5 visualized (a) at $366 \mathrm{~nm}$; (b) under white light. Mobile phase: acetic acid-water-butanol (15:30:60, v/v/v), applied volumes: Mallow-7 $\mu \mathrm{L}$, other extracts-9 $\mu \mathrm{L}$, derivatization: $\mathrm{H}_{2} \mathrm{SO}_{4}$ reagent. Tracks: (1) Alcea sp. whole flower (reference); (2) Mallow flower; (3) Alcea sp. corolla; (4) Alcea sp. calyx. 


\section{DISCUSSION}

In the present study, a monograph for "Althaeae flos" was proposed following the template for "Malvae sylvestris flos" in Ph. Eur. to be used in determination of the qualification of marshmallow flower samples and the developed template was applied for quality assessment of commercial marshmallow flower samples sold in herbal stores under the name of "hatmi çiçeği".

Macroscopic (Table 2) and microscopic (Table 3) examinations revealed that all commercial marshmallow samples had quite similar morphological and microscopic properties to those itemized under "Malvae sylvestris flos" monograph $[\mathrm{Ph}$. Eur.]. In addition, it was observed that six samples had stomata with three subsidiary cells, and only one sample had Malvaceae type glandular trichome. On the other hand, it was found that petal lengths of all commercial marshmallow samples were longer than the specified values for Althaea species [9-16 mm] ${ }^{1}$, but were similar to those issued for Alcea species [30 mm or longer]. ${ }^{39}$ Besides, two-locular ovary was observed in all marshmallow materials. As a result, it was considered that all commercial marshmallow samples were originally obtained from Alcea sp. flowers, but not from the official species Althaea officinalis. This is possibly due to widespread distribution of Alcea species in Turkey comparing to Althaea species.

In foreign matter analysis, only five samples were considered to be acceptable since they were free from insects or snails residues as well as the ratio of foreign elements were found to be lower than the set value 2.0\% (Table 4). On the other hand, $80 \%$ of the commercial marshmallow samples were found to be contaminated with insects, flies, snails and other animal wastes. The possible reason why these materials contain lots of such unacceptable matters is the closure of the petals during harvesting of the flowers, and the insects or flies collecting nectar from the flowers confined inside the closed flowers. Under these circumstances, it is not possible to prohibit such foreign substances without applying insecticide to the flowers, which would increase the health risk. For this reason, in contrast to Althaea or Alcea species, use of Malva sylvestris flowers does not have a risk for such contaminations and may be safely used.

In loss on drying test, it was detected that the rates of five commercial marshmallow samples and Alcea sp. were found to be more than $12.0 \%$, but the rates in the remaining 28 marshmallow materials were below this ratio. In total ash analysis, the ratio of all commercial marshmallow materials and Alcea sp. were found to be lower than $14.0 \%$. In swelling index test, it was determined that the results of all marshmallow materials and Alcea sp. were below the set value of 15 (Table 5), thus it was revealed that the mucilage content in marshmallow flowers was less than that in mallow flower. 
In HPTLC analysis (Figure 3 to Figure 7), when the chromatographic profiles at $366 \mathrm{~nm}$ were compared, it was determined that fourteen marshmallow samples presented 2 blue fluorescent zones and a red fluorescent zone in the upper part. In addition, blue fluorescent zones at $R_{f} 0.5$ and 0.9 were found in the chromatogram of twelve samples. This blue zone was also detected in the flower, corolla and calyx parts of Alcea sp. Furthermore, after spraying with $\mathrm{H}_{2} \mathrm{SO}_{4}$ reagent, under white light, blackish yellow spot between $\mathrm{R}_{\mathrm{f}} 0.2$ and 0.4 as well as dark yellow zone at $\mathrm{R}_{\mathrm{f}} \mathrm{0.8}$ were observed in twelve specimens.

\section{CONCLUSION}

Although the roots (Althaeae radix) and leaves (Althaeae folium) of Althaea officinalis are the officially accepted herbal drugs in Ph. Eur., only its flowers are available in the herbal markets in Turkey. In this study, primarily a draft monograph for the flowers was prepared in order to set its specifications. Then the commercial flower samples which are sold under the name of "hatmi çiçeği" in the herbal markets were analyzed for their compliance to the specifications set. These results have revealed that all the available "hatmi" flowers samples were obtained from Alcea sp., but not from Althaea. On the other hand, due to insect and snails parts as well as high ratio of foreign matter, including feathers, bristles, stones and foreign plant parts, which were detected in the flower samples in 28 out of 33 samples obtained from herbal markets, they were rated out of official use.

In the light of the discussed above, a template for Althaeae flos monograph is prepared as follows:

The values in the experimental sections of the "Althaeae flos" monograph were the results obtained from the tests carried out in this study. The ratio of foreign matter was found to be between 0.029 and 5.696\%. The mean calculated for 33 marshmallow samples was found to be 1.13. Maximum 2.0 per cent was approved as the amount of foreign matter by predicating on the general pharmacopeia rule.

In loss on drying test, the rates were between 9.74 and $13.25 \%$. The average of 33 marshmallow materials was found to be 10.99. When "Malvae sylvestris flos" monograph [Ph. Eur.] value and the average of findings were considered, maximum $12.0 \%$ was accepted as the quantity of loss on drying in the "Althaeae flos" monograph.

In total ash experiment, the lowest rate was $8.36 \%$, and the highest one was $13.52 \%$. The mean of 33 marshmallow materials was found to be 10.24 . When the results were taken into consideration, maximum 12.0\% was approved as the content of total ash in the "Althaeae flos" monograph.

In swelling index trial, the lowest value was 2.75, and the highest value was 8.33. 
The average of 33 marshmallow samples was 4.94. Regarding to the findings of trials, minimum 7 was accepted as the value of swelling index in the "Althaeae flos" monograph.

In TLC analyses, marshmallow specimens showed blue fluorescent spot and red fluorescent spot in the upper part of the chromatogram that was similar to Malvae sylvestris flos test solution [Ph. Eur.]. Considering the findings and TLC results stated in the "Malvae sylvestris flos" monograph, it is accepted that test solutions of marshmallow flowers exhibited a red spot in the upper part of the middle third and violet zone in the middle third.

According to the findings obtained from the Ph. Eur. analyses applied to all the samples and the evaluations of literature data, an "Althaeae flos" monograph prepared in $\mathrm{Ph}$. Eur. template is as follows.

\section{MARSHMALLOW FLOWER}

Althaeae flos

\section{DEFINITION}

Whole or fragmented dried flower of Althaea officinalis L. and Alcea species.

\section{IDENTIFICATION}

A. Flowers borne in fascicles in the leaf axils. The flower involves an epicalyx with 6-9 lanceolate segments, connate at the base and located below the calyx. A calyx with 5 pubescent triangular lobes, gamosepalous at the base, not inflated. A corolla with 5 petals white to pinkish white, fused to the staminal tube at the base. Style much branched at the apex. Althaea petals 9-14 mm, Alcea petals $30 \mathrm{~mm}$ or more. Stamens numerous, the filaments of which fuse into a staminal tube covered by simple trichomes and small stellate trichomes visible using a lens. Althaea anthers brownish purple, Alcea anthers yellowish. Carpels numerous, glabrous, in one series around the base of the styles, 1-ovulate. Althaea carpels unilocular, Alcea carpels sub-bilocular. Fruit a schizocarp, splitting into numerous 1-seeded, indehiscent mericarps. Mericarps rugose, stellate-pilose.

B. Reduce to a powder (355) (2.9.12). The powder is pinkish white. Examine under a microscope using chloral hydrate solution $R$. The powder displays the following diagnostic characters (Figure 8): unicellular, thick-walled trichomes; small unicellular covering trichomes, somewhat curved [A] or in star-shaped groups of 2-9 [B]; capitate glandular trichomes with multicellular heads [C]; mesophyll fragments with cluster crystals of calcium oxalate [D]; veins of sepals with vessel [E]; fragments of petal epidermis [F] accompanied by glandular trichomes with multicellular heads [G]; numerous spherical pollen grains with a spiny exine, $140-160 \mu \mathrm{m}$ in diameter $[\mathrm{H}]$. 
$\mathbf{A}$

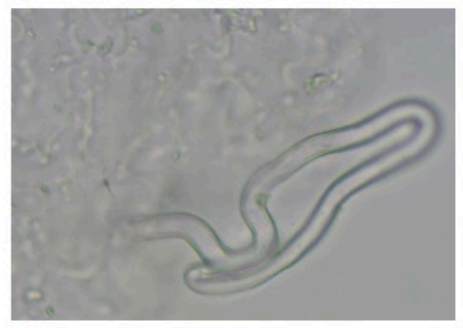

C

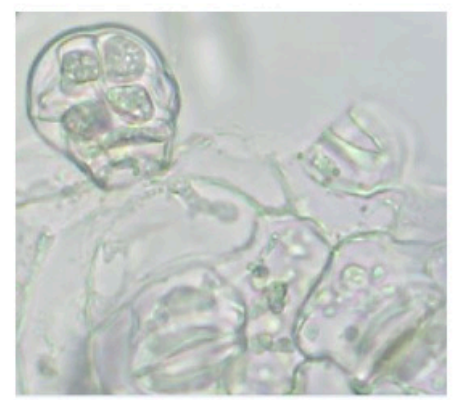

$\mathbf{E}$

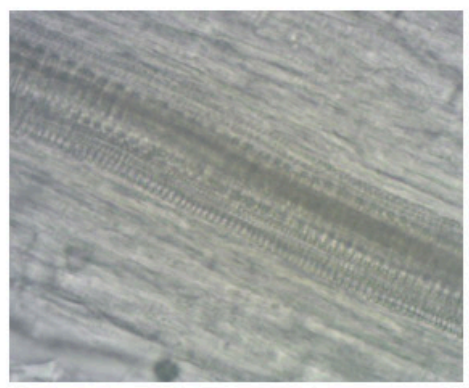

G

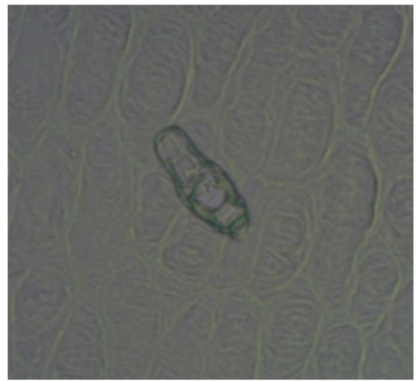

B

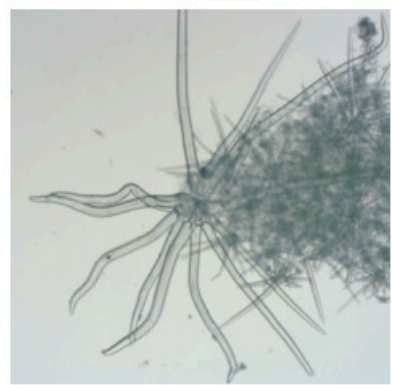

D

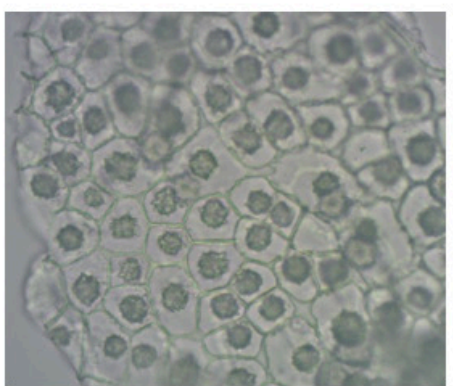

$\mathbf{F}$

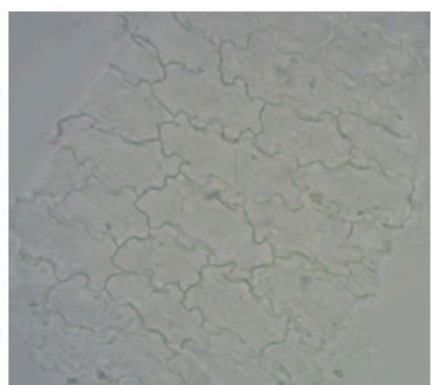

$\mathbf{H}$

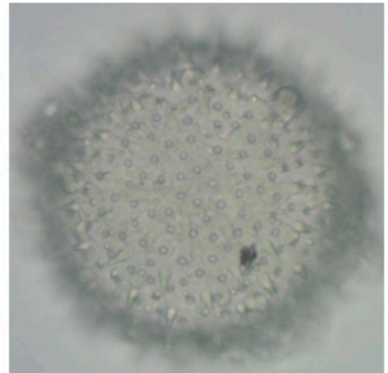

Figure 8. Illustration for identification test B of powdered herbal flower drug: $(A)$ curved trichome; (B) stellate trichome; (C) glandular trichome; (D) mesophyll fragments with cluster crystals of calcium oxalate; (E) vessel; (F) petal epidermis; (G) petal epidermis accompanied by glandular trichome with multicellular heads; (E) pollen grain. 
C. Thin-layer chromatography (2.2.27).

Test solution. To $1 \mathrm{~g}$ of the pulverized drug (355) (2.9.12) add $10 \mathrm{~mL}$ of ethanol (6o per cent, $v / v$ ) R. Stir for $15 \mathrm{~min}$ and filter.

Plate: TLC silica gel plate $R$.

Mobile phase: acetic acid $R$, water $R$, butanol $R$ (15:30:60, v/v/v).

Application: $9 \mathrm{~mL}$ of test solution, as $9.0 \mathrm{~mm}$ bands.

Development: over a path of $10 \mathrm{~cm}$.

Drying: in air.

Detection: examine in daylight, ultraviolet light at $366 \mathrm{~nm}$, spray with sulphuric acid solution (5 per cent) and exsiccate in an oven at $105^{\circ} \mathrm{C}$.

Results: chromatogram attained with test solution exhibits red zone in the upper part of the middle third and violet zone in the middle third.

\section{TESTS}

Foreign matter (2.2.32): maximum 2.0 per cent

Loss on drying (2.4.16): maximum 12.0 per cent, detected on $1.000 \mathrm{~g}$ of the pulverized herbal drug by desiccating in an oven at $105^{\circ} \mathrm{C}$ for 2 hours.

Total ash (2.8.1): maximum 12.0 per cent.

Swelling index (2.8.4): minimum 7 , detected on $0.2 \mathrm{~g}$ of the pulverized herbal drug (710) (2.9.12) moistened with $0.5 \mathrm{~mL}$ of ethanol $R$.

\section{REFERENCES}

1. Cullen, J. Althaea L. In Flora of Turkey and the East Aegean Islands; Davis, P. H., Ed.; Edinburgh University Press: Edinburgh, 1967; pp 419-420.

2. Marshmallow - Althaea officinalis. In PDR for Herbal Medicines; Medical Economics Company: Montvale, 2000; pp 505-506.

3. Radix Althaeae. In WHO Monographs on Selected Medicinal Plants; World Health Organization: Malta, 2002; pp 5-11.

4. Baytop, T. Therapy with Medicinal Plants in Turkey, 2nd ed.;. Nobel Tip Kitabevleri: İstanbul, 1999.

5. Sezik, E.; Yeşilada, E.; Honda, G.; Takaishi, Y.; Takeda, Y.; Tanaka, T. Traditional medicine in Turkey X. folk medicine in Central Anatolia. $J$ Ethnopharmacol. 2001, 75, 95-115.

6. Sağlam, H. Althaea officinalis. In Tedavide Kullamılan Bitkiler - "FFD monograflar"; Demirezer, Ö., Ed.; Nobel Tip Kitabevleri: Ankara, 2007; pp 35-39.

7. Sargin, S. A.; Selvi, S.; Büyükcengiz, M. Ethnomedicinal plants of Aydınclk district of Mersin, Turkey. J Ethnopharmacol. 2015, 174, 200-216. 
8. Kobayashi, A.; Hachiya, A.; Ohuchi, A.; Kitahara, T.; Takema, Y. Inhibitory mechanism of an extract of Althaea officinalis L. on endothelin-1-induced melanocyte activation. Biol Pharm Bull. 2002, 25, 229-234.

9. Gudej, J.; Dzido, T. H. Quantitative determination of flavonoid glycosides in leaves and flowers from some species of Althaea genus using HPLC technique. Acta Pol Pharm. 1991, 48, 59-62.

10. Didry, N.; Torck, M.; Pinkas, M. Polyphenolic compounds from the flowers of Althaea officinalis. Fitoterapia. 1990, 61, 280.

11. Dzido, T. H.; Soczewinski, E.; Gudej, J. Computer-aided optimization of High-Performance Liquid Chromatographic analysis of flavonoids from some species of the genus Althaea. JChromatogr. 1991, 550, 71-76.

12. Gudej, J.; Bieganowska, M. L. Chromatographic investigations of flavonoid compounds in the leaves and flowers of some species of the genus Althaea. Chromatographia. 1990, 30, 333336.

13. Gudej, J. Polyphenolic compounds in Althaea officinalis flowers. Acta Pol Pharm. 1988, $45,340-345$.

14. Gudej, J.; Bieganowska, M. L. Chromatographic investigations of phenolic acids and coumarins in the leaves and flowers of some species of the genus Althaea. J Liq Chromatogr. 1990, 13, 4081-4092.

15. Gudej, J. Determination of flavonoids in leaves, flowers, and roots of Althaea officinalis L. Farm Pol. 1990, 46, 153-155.

16. Elmastas, M.; Ozturk, L.; Gokce, I.; Erenler, R.; Aboul-Enein, H. Y. Determination of antioxidant activity of marshmallow flower (Althaea officinalis L.). Anal Lett. 2004, 37, 1859-1869.

17. Sadighara, P.; Gharibi, S.; Jafari, A. M.; Khaniki, G. J.; Salari, S. The antioxidant and flavonoids contents of Althaea officinalis L. flowers based on their color. Avicenna J Phytomed. 2012, 2, 113-117.

18. Hage-Sleiman, R.; Mroueh, M.; Daher, C. F. Pharmacological evaluation of aqueous extract of Althaea officinalis flower grown in Lebanon. Pharm Biol. 2011, 49, 327-333.

19. Valiei, M.; Shafaghat, A.; Salimi, F. Chemical composition and antimicrobial activity of the flower and root hexane extracts of Althaea officinalis in northwest Iran. $J$ Med Plants Res. 2011, 5, 6972-6976.

20. Heinrich, M.; Barnes, J.; Gibbons, S.; Williamson, E. M. Fundamentals of Pharmacognosy and Phytotherapy. Churchill Livingstone: Edinburgh, 2004.

21. Mills, S.; Bone, K. Marshmallow. In The Essential Guide to Herbal Safety; Churchill Livingstone: United States of America, 2005; pp 505-506.

22. Barnes, J.; Anderson, L. A.; Phillipson, J. D. Marshmallow. In Herbal Medicines; Pharmaceutical Press: London, 2007; 418-420.

23. Saric-Kundalic, B.; Dobes, C.; Klatte-Asselmeyer, V.; Saukel, J. Ethnobotanical study on medicinal use of wild and cultivated plants in middle, south and west Bosnia and Herzegovina. J Ethnopharmacol. 2010, 131, 33-55.

24. Ramirez, V. R.; Mostacero, L. J.; Garcia, A. E.; Mejia, C. F.; Pelaez, P. F.; Medina, C. D.; Miranda, C. H. Vegetables empleados en Medicina Tradicional Norperuana; Banco Agrario 
Del Peru and NACL Univ Trujillo: Peru, 1988.

25. Novaretti, R.; Lemordant, D. Plants in the traditional medicine of the Ubaye valley. $J$ Ethnopharmacol. 1990, 30, 1-34.

26. Shome, U.; Mehrotra, S.; Sharma, H. P. Comparative pharmacognosy of two Althaea spp. and gulkhairo samples. Int $J$ Pharmacog. 1992, 30, 47-55.

27. De Feo, V.; Senatore, F. Medicinal plants and phytotherapy in the Amalfitan coast, Salerno province, Campania, southern Italy. J Ethnopharmacol. 1993, 39, 39-52.

28. Hanlidou, E.; Karousou, R.; Kelftoyanni, V.; Kokkini, S. The herbal market of Thessaloniki (N Greece) and its relation to the ethnobotanical tradition. J Ethnopharmacol. 2004, 91, 281299.

29. Miraldi, E.; Ferri, S.; Mostaghimi, V. Botanical drugs and preparations in the traditional medicine of West Azerbaijan (Iran). J Ethnopharmacol. 2001, 75, 77-87.

30. Newall, C. A.; Anderson, L. A.; Phillipson, J. D. Marshmallow. In Herbal medicines - a Guide for Health-Care Professionals. Pharmaceutical Press: London, 1996; pp 188.

31. Bradley, P. Marshmallow leaf. In British Herbal Compendium - A handbook of scientific information on widely used plant drugs companion to the British Herbal Pharmacopoeia. British Herbal Medicine Association: Exeter, 2006; pp 262-264.

32. Turan, F. Türkiye’de Halk İlacı Araştırmaları. T.C. Kültür Bakanlığı: Ankara, 200.

33. Özgökçe, F.; Özçelik, H. Ethnobotanical aspects of some taxa in East Anatolia, Turkey. Econ Bot. 2004, 58, 697-704.

34. Marshmallow leaf. In European Pharmacopoeia, 8th ed.; Council of Europe: Strasbourg, France, 2014; pp 1309-1310.

35. Marshmallow root. In European Pharmacopoeia, 8th ed.; Council of Europe: Strasbourg, France, 2014; pp 1310-1311.

36. Guimauve. In French Pharmacopoeia, 8th ed.; France, 1965; pp 552-553.

37. Mallow flower. In European Pharmacopoeia, 8th ed.; Council of Europe: Strasbourg, France, 2014; pp 1305-1306.

38. Cullen J. Malvaceae. In Flora of Turkey and the East Aegean Islands; Davis, P. H., Ed.; Edinburgh University Press: Edinburgh, 1967; pp 401-402.

39. Cullen J. Alcea L. In Flora of Turkey and the East Aegean Islands; Davis, P. H., Ed.; Edinburgh University Press: Edinburgh, 1967; pp 411-419. 